\title{
SEXUAL HARASSMENT OF SYRIAN FEMALE YOUTH IN JORDANIAN REFUGEE CAMPS
}

\section{Mohammed Abdel Karim Al-Hourani, Abdel Baset Azzam, and Addison J. Mott}

\begin{abstract}
This study aimed at documenting the sexual harassment of Syrian female refugees in refugee camps in Jordan. A purposive sample of 187 Syrian female refugees in the Za'atari camp was selected. The results showed that the environment of the camp played an important role in motivating males to harass females owing to the weakness of the security measures and the lack of sanctions upon deviant behaviors. Our findings show that females were subjected to numerous forms of sexual harassment, including hearing sexual jokes and sexual expressions, and being subjected to suggestive looks, sexual letters, and unwanted touching. Additionally, our results revealed that participants responded to sexual harassment by keeping silent because they feared making their situation worse by provoking conflict within their families. This left the victims without protection or the chance to obtain justice.
\end{abstract}

Keywords: Syrian female, sexual harassment, refugees, Jordan

Mohammed Abdel Karim Al-Hourani PhD (the corresponding author) is an Associate Professor of Applied Sociological Theory in the Sociology Department at the University of Sharjah, P. O. Box 27272, Sharjah, UAE. Email: malhourani@sharjah.ac.ae. Professor Al-Hourani can also be reached at Yarmouk University, Irbid, Jordan. Email: mhorani@yu.edu.jo

Abdel Baset Azzam PhD is an Assistant Professor of Political Sociology at Yarmouk University, Irbid, Jordan. Email: Abdazzam72@yahoo.com

Addison J. Mott is an MA candidate at the School of Child and Youth Care, Human \& Social Development Building B102A, University of Victoria, BC V8W 2Y2, Canada. Email: addisonmott@uvic.ca 
International Journal of Child, Youth and Family Studies (2019) 10(4.1): 24-43

The Syrian war has forced thousands of Syrian women refugees to escape with their families to Arab and European countries in search of a safer life. Jordan is one of the countries in which thousands of Syrian families have sought refuge, settling in camps close to the Syrian border.

The office of the UN High Commissioner for Refugees estimated the number of fugitives from the bloody war in Syria who had fled to neighboring countries - Lebanon, Turkey, Jordan, Iraq, and Egypt - to have reached 5.6 million, nearly $80 \%$ of them women and children (UNHCR, 2019). The Za'atari camp lies 85 kilometres to the northeast of Amman, Jordan's capital. It is the largest Syrian refugee camp in the Middle East and the second largest in the world. At the beginning of 2015 it included 81 thousand refugee (Jordan Statistical Yearbook, 2015).

Mas'ood (2017) noted that according to international reports, women refugees in all hosting countries have been exposed to sexual assault, harassment, and trafficking. News organizations have reported that the civil war in Syria exposed hundreds of females to sexual harassment and assault ("Shocking stories," 2013). Girls between 12 and 16 years old have been sold as servants to people from the Gulf countries (Al-Jundi, 2016). In the Za'atari camp, international relief organizations are unable to meet the needs of refugees for food and drink, and for adequate heating facilities - needs that arise from the absence of work opportunities that could allow them enough income to live independently. Among other consequences, these factors lead to the spread of diseases in the camp.

Along with being subject to the harassment and multiple deprivations noted above in the Za'atari camp, it has been well documented globally that displaced women and girls are at a higher risk than non-displaced women and girls of sexual and gender-based violence (SGBV) and sexual harassment (United Nations High Commissioner for Refugees, 2008), and that such violence and harassment are used as weapons of war (Asaf, 2017). Syrian women and girls who are refugees in Lebanon, Turkey, and Jordan face ongoing issues of SGBV and sexual harassment; these risks may be expected to increase as long as the situation in Syria continues unabated (Samari, 2017; Sami et al., 2014). However, only a handful of studies have focused specifically on SGBV and sexual harassment in Jordan, and few have focused on Jordanian refugee camps. This is indicative of the fact that SGBV and sexual harassment have been understudied and underreported for Syrian refugee women and girls compared to other refugee groups (Asaf, 2017). A search of the recent literature on the experiences of Syrian women and girls after becoming refugees yielded four relevant studies, which are presented below in chronological order, but our current knowledge in this area is still limited.

The first study we reviewed is the UN Women's (2013) report entitled "Gender-Based violence and child protection among Syrian refugees in Jordan, with a focus on early marriage". This study included an inquiry into SGBV experienced by Syrian refugees living in urban settings, 
not the Za'atari camp. Data were collected through a questionnaire distributed to 613 Syrian refugees, focus groups, and 45 in-depth interviews with key informants including community leaders and service providers. The report found that gender-based violence (GBV) most often "remains a private and sensitive issue" (p. 2), rarely discussed outside the home. Women were significantly more likely "to report any form of violence to other family members, rather than to service providers or the police, and many felt more comfortable reaching out to a religious official" (p. 2). The report concludes that while the need for additional services is significant, the main issue from a service provision perspective is "building trust and reaching out to the communities" (p. 3).

The second study was conducted by Krause et al. (2015) who studied two Syrian refugee sites in Jordan, the Za'atari camp and Irbid City, in order to research the status of the minimum initial service package (MISP; Inter-Agency Working Group on Reproductive Health in Crisis, n.d.) for reproductive health implementation among the refugees. The MISP has been used as a guideline for care in refugee situations since it was published in 1996. Krause and colleagues conducted 11 key informant interviews, 13 health facility assessments, and 14 focus group discussions involving 159 participants, which included both female youth (18 to 24 years) and older women (25 to 49 years). With regard to SGBV, Krause et al. reported that:

In Za'atari camp, women expressed concerns about the lack of lighting and their fears of using the toilets at night. In Irbid City, women reported feeling unsafe sending their daughters to school on public buses. Women said they were fearful of telling their families of sexual violence due to fears of honor killing, or being disowned by the family. The women discussed what they perceived as more cases of domestic violence in the camp than what they observed while living in Syria.... Additionally, all groups with young women said that they would not tell anyone if they experienced violence. (Results, para. 7)

The third study was conducted by Essaid et al. (2015) who investigated GBV perpetrated against female refugees from Syria living in the cities of Tyre and Sidon in Lebanon and Ajloun and Jerash in Northern Jordan. These researchers held focus group discussions about participants' perceptions of violence trends with 94 female participants under the age of 60, all either refugees from Syria - including both Syrian nationals and Palestinians — or GBV case workers. Essaid et al. found that:

GBV is a significant problem in North Jordan and South Lebanon for refugee women and girls from Syria and frequently restricts their movement, causing them mental and physical distress, and occurs both inside and outside the home. The most common form of violence reported by particpants was emotional violence, however, a large number also reported sexual violence. Among those who reported violence, most indicated that they had been subjected to multiple types of violence. ... In general, women and girls felt that severe poverty, men's and women's 
International Journal of Child, Youth and Family Studies (2019) 10(4.1): 24-43

inability to perform traditional gender roles, and rising prices, are contributing factors to women's and girls' experiences of GBV. (p. 4)

Participants in Essaid et al.'s study (2015) speculated that Syrian women refugees who had lost the protection of their families were seen to be "easy targets" (p. 4). Finally, participants noted that they "were often reluctant to tell anyone about the violence for fear of being blamed for causing the violence or being blamed for inciting further violence" (p. 5).

The most recent study we reviewed was conducted by Hattar-Pollara (2019). In this study, multiple methods such as focus group discussions, interviews, and observation were used to explore Syrian refugee girls' experiences of barriers to education in the Za'atari camp. The study participants included refugee girls aged between 5 and 16 years, their teachers, counsellors, child protective agents, and mothers, and three religious clerks. Hattar-Pollara found that refugee girls in the camp encountered many barriers to continuing their education. For example, they experienced gender-based physical and psychological violence, and the social barriers of early marriage and poverty. She also found that coercive early marriage, while often viewed as a way of protecting Syrian refugee girls, also contributed to the multiple challeges faced by them. Furthermore, she noted that girls who had experienced SGBV were more likely to experience posttraumatic stress disorder, dissociative disorders, depression, and anxiety, along with a host of lifethreatening physical health conditions.

Taken together, this body of literature outlines the pervasiveness of the SGBV and sexual harassment experienced by Syrian women and girls living as refugees in Jordan. While the literature is still too sparse to allow confident generalizing, existing research outlines how SGBV and sexual harassment in the Za'atari camp translate into an ongoing lack of safety in everyday life for women and girls. Moreover, this lack of safety is heightened in specific situations, such as going to the washroom. Further, Syrian women and girls in the Za'atari camp experience ongoing fear about reporting instances of SGBV and sexual harassment because of the possibility of inciting further violence. These experiences of SGBV and sexual harassment entail physical and mental health risks and lead to ongoing experiences of violence, exploitation, abuse, and poverty. The literature reviewed here suggests that these constant threats and violations and their related deleterious health outcomes extend beyond the camp itself, indicating that SGBV and sexual harassment are also commonly experienced by Syrian women and girls living as refugees in urban Jordanian centres.

Al-Jundi (2016) pointed out that, in response to the many serious challenges faced by female refugees, the Jordanian Women's Union launched 'the 'Yes' campaign to close Al-Zaatari Camp", calling for alternatives more consistent with the Syrians' human dignity. Educated people and lawmen from Jordan also demanded the closure of the camp, terming it a disgrace to Jordan (Al-Jundi, 2016). 
International Journal of Child, Youth and Family Studies (2019) 10(4.1): 24-43

Following on the above work, the study that we report on here aimed to answer the following questions: (a) What are the environmental motivations that encourage males to harass females in the Za'atari camp? (b) How do female refugees respond to the harassment in the camp? and (c) In what situations are females exposed to sexual harassment in the camp?

\section{Syrian Female Refugees in the Za'atari Camp}

Of the five camps for Syrian refugees in Jordan, which house 300,000 refugees in total, the biggest is Za'atari with 160,000 refugees; the rest are distributed among Mereejib Al Fuhod, AlAzraq, Al-Hadiqah, and Cyber City (Al-Shreefeen \& Al-Rifa'i, 2016). According to some accounts, the Za'atari camp has the highest incidence of prostitution. Participation in the sex trade is widespread among Syrian female refugees. Hundreds of underaged girls have been victims of this trade, offered by their families to be sold for days or hours at a time in return for money as a bride price (Migdadi, 2017, Al-Ghazali, 2018).

The British Daily Telegraph newspaper reported in 2013 that the Za'atari camp had become a market for selling Syrian female refugees of 14 years old or younger, with the girls being forced to "marry" for a set period of hours or weeks, or to practice prostitution (Sherlock \& Malouf, 2013) The desperate lives of the Syrian female refugees made marriage to wealthy Arabs an attractive choice for many of them as a means of escape from the wretchedness of life in the camp. Most of these marriages are arranged in the interests of slave owners from other countries, often Saudi Arabia. Such slave owners rent hours for their temporary wives outside the camp and are committed to paying expenditures before the divorce, which take place after a short time (Al-Jundi, 2016).

The Jafra News website reported ("Syrian women describe," 2012) that Syrian refugee women in the Za'atari camp were in some instances obliged to marry men older than their fathers. Overall, the proportion of underage marriages among Syrian female refugees rose to 35\% (about 500 marriages) in 2015 from 18\% in 2013 and 25\% in 2014 (Abu-Tarboush, 2014; Al-Khateeb, 2013).

Haddadin (2014) reported on a study showing that Syrian female refugees are subject to violence as well as sexual harassment, and after having experienced these violations, may be negatively viewed within the community as a consequence. Slave owners considered female refugees a cheap commodity in the camp; unfortunately, most of the refugees were unaware of organizations that offer legislative and social guidance and protection from violence (Haddadin, 2014).

Sexual harassment by laborers working at the camp has also been reported. Jefra News Agency (2012) interviewed Syrian female refugees who reported being sexually harassed. Fatin, aged 29, wiped away tears as she recalled an occasion when four maintenance laborers harassed her sexually in co-baths in the Za'atari camp. "How hard it is for us to be treated as if we were slaves!" she said, adding, "I am afraid of staying here... I always live with nightmares." She 
International Journal of Child, Youth and Family Studies (2019) 10(4.1): 24-43

recalled the frightening moments of screaming to attract help from people living in nearby tents as the four men tried to rape her.

Basma, a 20-year-old Syrian girl, reported:

I came here alone among hundreds of refugees.... My family was killed by cannon fire in Da'el town in Der'a city, two months ago. ... We are suffering humiliation and enslaving of dignity. ... We can't ask the police to prevent people from coming to the camp. ... Everybody ${ }^{1}$ comes here pretending to help and offer food and drink.

Women and girls in the Za'atari camp live in fear of sexual violence and sexual harassment. They are afraid of going to bathrooms alone at night lest they should be harassed. Doctors have reported that women in the camp suffer an increased rate of urinary tract inflammation due to abstaining from using bathrooms for long periods of time (Abu-Tarboush, 2014; "Amnesty International: Syrian refugees", 2013).

An article on Al-Mada.org (“Za'atari Camp", 2013) reported Syrian female refugees being subjected to sexual offences in camps outside Syria, especially Za'atari camp:

A lot of women in Al-Za'atari camp are exposed to sexual offences and rape in the camp, where the idea of the safety and security of which the women dream fades when they enter Jordan. The problem is made worse by the fact that the female refugees who suffer such treatment remain silent about it because of the conservative environment they came from.

In Jordanian newspaper articles concerning Syrian female refugees, one notices that the news is reported from a perspective that regards the women as goods, and emphasizes their humiliation rather than revealing them as victims of circumstances beyond their control. One encounters headlines such as, "Marrying Syrians secretly", "Marrying a female refugee for 150 dollars", "Early marriages spread among Syrian female refugees", "Provision of Syrian refugees for marriage", "Female refugees for sex". "Forcing female refugees to practise prostitution", "Female refugees for sale", and "Syrian female refugees resort to prostitution in Jordan". Such titles give a negative impression of Syrian women based on stereotypes of injustice and tyranny (Al-Hourani, 2016).

In order to examine at first hand the current situation that girls and women face in the Za'atari camp, we conducted a study aimed at documenting the forms of sexual harassment that Syrian refugee girls and women endure in the refugee camps. Furthermore, this study aimed to document the extent to which the camps' environment represents a tolerant context for sexual harassment, and the role of camp authorities in protecting families from being sexually harassed.

\footnotetext{
${ }^{1}$ Basma is referring here to service providers such as food and water suppliers.
} 
International Journal of Child, Youth and Family Studies (2019) 10(4.1): 24-43

Another important goal of the study was to determine how the female refugees responded to the sexual harassment they experienced.

\section{Method}

\section{Participants}

A volunteer sample of 187 participants answered the sexual harassment questionnaire, as well as giving demographic information (see Appendix A). The sample of this study represented Syrian female refugee youth living in the Za'atari camp ranging in age from 15 to 24 years. The sample was selected purposively to ensure that the ages of the participants were within the specified range. The researchers were assisted in recruiting participants by some foreign agencies, by the authorities of the camp, and by harassed girls who guided us to their female friends who were also being sexually harassed. The agreement of each participant was secured, and sometimes that of her husband, father, or brother, since the study topic has cultural sensitivity. Furthermore, data were collected with private access to the camp as the camp's Jordanian authorities do not allow research into such sensitive topics in the camp.

\section{Instrument}

The sexual harassment questionnaire consisted of 27 items representing three dimensions. Each item is measured on a 4-point scale, ranging either from 1 (strongly disagree) to 4 (strongly agree), or from 1 (not at all) to 4 (to a large degree). The dimensions of the scale were: (a) motivational environment of sexual harassment in the camp (lack of control and order in the camp facilitating sexual harassment); (b) responding to harassment; and (c) pervasive harassment incidents in the camp. The questionnaire was written and administered in Arabic.

Table 1. Reliability of the Three Dimensions of Sexual Harassment in the Camp

\begin{tabular}{lcc}
\hline Dimension & Eigenvalue & Cronbach's Alpha \\
\hline Motivational environment of harassment & 3.156 & .78 \\
Victim's response to harassment & 1.756 & .75 \\
Types of harassment seen as pervasive & 1.666 & .74 \\
\hline
\end{tabular}

The content validity of the scale was assessed by seven specialists who judged the suitability of each item in measuring the dimension to which it belongs. The scale has discriminant validity: correlation coefficients between items and the subscales to which they belong were significant $(p<.001)$. The reliability of the scale is acceptable with regard to internal consistency as shown in Table 1. 
International Journal of Child, Youth and Family Studies (2019) 10(4.1): 24-43

\section{Results}

Table 2. Participant Demographics and Responses Regarding Sexual Harassment

\begin{tabular}{|c|c|c|c|}
\hline Variable & Category & $n$ & Percent \\
\hline \multirow[t]{2}{*}{ Age } & $15-20$ & 126 & 67.4 \\
\hline & $21-24$ & 61 & 32.6 \\
\hline \multirow[t]{4}{*}{ Marital status } & Single & 67 & 35.8 \\
\hline & Married & 108 & 57.8 \\
\hline & Divorced & 7 & 3.7 \\
\hline & Widow & 5 & 2.7 \\
\hline \multirow[t]{5}{*}{ Educational attainment } & Illiterate & 8 & 4.3 \\
\hline & Elementary & 31 & 16.6 \\
\hline & Preparatory & 111 & 59.4 \\
\hline & Secondary & 25 & 13.4 \\
\hline & University degree & 12 & 6.4 \\
\hline Have you ever been harassed in the camp? & Yes & 187 & 100.0 \\
\hline \multicolumn{4}{|c|}{ If you answered yes to the previous question, please also answer the following questions. } \\
\hline \multirow[t]{3}{*}{ Where you have been sexually harassed? } & Streets & 69 & 36.9 \\
\hline & Shops (mini market) & 79 & 42.2 \\
\hline & Restrooms & 39 & 20.9 \\
\hline \multirow[t]{4}{*}{ How many times have you been harassed? } & Once & 17 & 9.1 \\
\hline & Twice & 48 & 25.7 \\
\hline & Three times & 41 & 21.9 \\
\hline & Four or more times & 81 & 43.3 \\
\hline \multirow[t]{4}{*}{ At what time of day did the harassment occur? } & In the morning & 33 & 17.6 \\
\hline & At noon & 57 & 30.5 \\
\hline & In the evening & 48 & 25.7 \\
\hline & At multiple times & 49 & 26.2 \\
\hline \multirow[t]{4}{*}{ What form of harassment did you undergo? } & Verbal & 77 & 41.2 \\
\hline & $\begin{array}{l}\text { Symbolic (gestures } \\
\text { and body language) }\end{array}$ & 34 & 18.2 \\
\hline & Behavioral & 36 & 19.3 \\
\hline & Social media & 40 & 21.4 \\
\hline \multirow{4}{*}{$\begin{array}{l}\text { Do you believe that sexual harassment is pervasive in the } \\
\text { camp? }\end{array}$} & Strongly agree & 98 & 52.4 \\
\hline & Agree & 66 & 35.3 \\
\hline & Disagree & 16 & 8.6 \\
\hline & Strongly disagree & 7 & 3.7 \\
\hline
\end{tabular}

Note. $N=187$. Each question was answered by all participants $(100 \%)$. 
The descriptive statistics illustrated in Table 2 indicate that most of the participants were 15 to 20 years old $(67.4 \%)$ and most were married (57\%). This result accords with the fact that the marriage of female minors is widespread in refugee camps. Furthermore, 59.4\% of participants had received only basic education and only $13.4 \%$ had attained a university degree; this is consistent with reporting from international agencies indicating that young refugees often don't complete their education. All participants $(100 \%)$ reported that they had been harassed in the streets, shops, and restaurants. A large majority (87.7\%) strongly agreed that sexual harassment is pervasive in the camp.

Table 3. Motivational Environment of Sexual Harassment

\begin{tabular}{clccc}
\hline Rank & \multicolumn{1}{c}{ Item } & $M$ & $S D$ & Estimation \\
\hline $\mathbf{1}$ & $\begin{array}{l}\text { There are no sanctions against harassment in } \\
\text { the camp }\end{array}$ & 3.18 & .848 & High \\
$\mathbf{1}$ & $\begin{array}{l}\text { Males recognize that they are able to violate } \\
\text { rules without being punished }\end{array}$ & 3.18 & .865 & High \\
$\mathbf{3}$ & $\begin{array}{l}\text { Males recognize that there is an absence of } \\
\text { surveillance }\end{array}$ & 3.15 & .854 & High \\
$\mathbf{4} \quad \begin{array}{l}\text { There are no controlling procedures in the } \\
\text { camp }\end{array}$ & 3.12 & .830 & High \\
$\mathbf{4} \quad \begin{array}{l}\text { Males are not regulated by moral guidance } \\
\text { from their families }\end{array}$ & 3.12 & .934 & High \\
$\mathbf{6}$ & $\begin{array}{l}\text { There are no clear procedures for punishing } \\
\text { harassment }\end{array}$ & 3.02 & .967 & High \\
$\mathbf{7}$ & $\begin{array}{l}\text { The camp environment doesn't provide the } \\
\text { minimum level of deterrence }\end{array}$ & 2.98 & .944 & Moderate \\
$\mathbf{8}$ & $\begin{array}{l}\text { Males are able to do what they want in the } \\
\text { camp }\end{array}$ & 2.94 & 1.058 & Moderate \\
$\mathbf{9} \quad \begin{array}{l}\text { There is an absence of official authorities to } \\
\text { prevent harassment }\end{array}$ & 2.64 & 1.285 & Moderate \\
\hline
\end{tabular}

Table 3 shows that Syrian female refugees strongly agreed that the environment of the camp motivates males to commit sexual harassment. They noted that the camp doesn't include sanctions and controls against harassment, and that males recognize the absence of surveillance and realize that they are able to violate morals and regulations. These findings demonstrate that the camp environment is dangerous and intimidating for females, and threatening to their existential security. We may speculate that this also indicates that the camp authorities don't prioritise social control and upholding the moral level of behaviour within the camp, and that the one thing that does concern them is controlling the camp boundaries. We may also speculate that under these dire conditions, families in the camp don't pay enough attention to controlling their sons and preventing them from engaging in offensive or illegal behaviors.

Table 4. Victim's Responses to Harassment 
International Journal of Child, Youth and Family Studies (2019) 10(4.1): 24-43

\begin{tabular}{|c|c|c|c|c|}
\hline Rank & Item & $M$ & $S D$ & Estimation \\
\hline 1 & Being too scared to do anything & 3.16 & .890 & High \\
\hline 2 & $\begin{array}{l}\text { Keeping silent to avoid worsening the } \\
\text { problem }\end{array}$ & 3.14 & .905 & High \\
\hline 3 & Telling close friends only & 3.08 & .885 & High \\
\hline 4 & Resisting the man strongly and loudly & 2.57 & 1.274 & Moderate \\
\hline 5 & $\begin{array}{l}\text { Expressing satisfaction at successfully } \\
\text { avoiding further incidents }\end{array}$ & 2.20 & 1.006 & Moderate \\
\hline 6 & $\begin{array}{l}\text { Telling family members immediately } \\
\text { after the incident }\end{array}$ & 1.95 & 1.147 & Low \\
\hline \multirow[t]{2}{*}{7} & Telling official authorities in the camp & 1.78 & .868 & Low \\
\hline & Total & 2.56 & .410 & Moderate \\
\hline
\end{tabular}

Where victims' responses to harassment are concerned, participants generally responded to the harassment passively, as shown in Table 4. They reported remaining silent, being scared, and telling close friends only. Some victims did resist loudly, while others expressed satisfaction at having avoided further assaults. Passive responses could be expected to reproduce harassment in the camp and enhance the frequency of assaults and other undesirable behaviors.

Table 5. Pervasive Harassment Incidents

\begin{tabular}{|c|c|c|c|c|}
\hline Rank & Item & $M$ & $S D$ & Estimation \\
\hline 1 & $\begin{array}{l}\text { Males making sexual jokes within the hearing of } \\
\text { females }\end{array}$ & 3.18 & .848 & High \\
\hline 2 & $\begin{array}{l}\text { Females receiving sexually suggestive and } \\
\text { aggressive looks }\end{array}$ & 3.17 & .855 & High \\
\hline 3 & $\begin{array}{l}\text { Females hearing expressions that make them } \\
\text { uncomfortable }\end{array}$ & 3.14 & .749 & High \\
\hline 4 & $\begin{array}{l}\text { Females being exposed to sexual expressions that } \\
\text { violate modesty }\end{array}$ & 3.12 & .821 & High \\
\hline 4 & Uninvited pressure for sexual favor & 3.12 & .902 & High \\
\hline 6 & Males chasing females & 3.10 & .895 & High \\
\hline 7 & Males luring females to obtain sexual favors & 3.10 & .905 & High \\
\hline 8 & $\begin{array}{l}\text { Females receiving threats to keep silent after being } \\
\text { harassed }\end{array}$ & 3.09 & .900 & High \\
\hline 9 & $\begin{array}{l}\text { Females receiving letters, telephone calls, or } \\
\text { materials of a sexual nature }\end{array}$ & 3.06 & .887 & High \\
\hline 10 & Males making sexual remarks to females & 3.00 & .978 & Moderate \\
\hline \multirow[t]{2}{*}{11} & Males touching females or leaning over them & 2.95 & .966 & Moderate \\
\hline & Total & 3.09 & .332 & High \\
\hline
\end{tabular}


Females in Arab culture routinely face gender discrimination, yet are obliged to maintain the honor of their families, who may regard harassment incidents as damaging to their reputation and even inflict punishment on the female victim as a result. One reason why families marry off their daughters at an early age is to protect family honor from the possibility of such an incident occurring. Furthermore, even if a family knows that their daughter has been sexually harassed, they may decide against making a formal complaint to the authorities for fear it will lead to scandal.

Females in the camp are subjected to many forms of sexual harassment. As listed in Table 5 , these include sexual jokes, expressions that make them uncomfortable or violate their modesty, suggestive and aggressive looks, pressure and luring to obtain sexual favors, and threats to secure their silence after being harassed.

Table 6. ANOVA Results from Table 3 (Motivational Environment of Sexual Harassment)

\begin{tabular}{|c|c|c|c|c|c|}
\hline Variable & Category & $M$ & $S D$ & $F$ & $p$ \\
\hline \multirow[t]{2}{*}{ Age } & $15-20$ & 3.04 & .414 & .125 & .724 \\
\hline & $21-24$ & 3.03 & .456 & & \\
\hline \multirow[t]{4}{*}{ Marital status } & Single & 3.05 & .368 & .286 & .835 \\
\hline & Married & 3.03 & .452 & & \\
\hline & Divorced & 2.95 & .475 & & \\
\hline & Widow & 3.13 & .645 & & \\
\hline \multirow[t]{5}{*}{ Education } & Illiterate & 3.08 & .524 & .977 & .422 \\
\hline & Elementary & 3.11 & .428 & & \\
\hline & Preparatory & 3.03 & .398 & & \\
\hline & Secondary & 3.05 & .475 & & \\
\hline & University degree & 2.82 & .520 & & \\
\hline \multirow{3}{*}{$\begin{array}{l}\text { Where have you been } \\
\text { harassed? }\end{array}$} & Streets & 3.04 & .420 & .807 & .448 \\
\hline & Shops (mini market) & 3.08 & .408 & & \\
\hline & Restrooms & 2.95 & .475 & & \\
\hline \multirow{4}{*}{$\begin{array}{l}\text { How many times have you been } \\
\text { harassed? }\end{array}$} & Once & 3.06 & .506 & .663 & .576 \\
\hline & Twice & 3.09 & .363 & & \\
\hline & Three times & 2.98 & .356 & & \\
\hline & Four times or more & 3.03 & .478 & & \\
\hline \multirow{4}{*}{$\begin{array}{l}\text { At what time of day did the } \\
\text { harassment occur? }\end{array}$} & In the morning & 2.99 & .459 & .332 & .802 \\
\hline & At noon & 3.01 & .446 & & \\
\hline & In the evening & 3.09 & .408 & & \\
\hline & At multiple times & 3.05 & .409 & & \\
\hline \multirow{5}{*}{$\begin{array}{l}\text { What form of sexual harassment } \\
\text { did you undergo? }\end{array}$} & Verbal & 2.96 & .415 & 2.182 & .092 \\
\hline & Symbolic & 3.02 & .491 & & \\
\hline & Behavioral & 3.15 & .400 & & \\
\hline & Social media & 3.10 & .399 & & \\
\hline & Total & 3.04 & .427 & & \\
\hline
\end{tabular}

Note: $\alpha=.05$. 
The results shown in Table 5 are consistent with Table 2, which shows that participants felt that males are able to do what they want without risking punishment, that males regard the camp as being without respected order or rules, and that the camp authorities are indifferent to the prevalence of the males' socially undesirable behaviors. A large majority of Syrian refugee youth are unemployed, and most drop out of school early. We therefore speculate that in many cases they fill the resulting vacuum in their lives with deviant or criminal behaviors such as assault, drug addiction, rape, and harassment.

The results captured in Table 6 show that there are no statistically significant differences in the motivational environment of sexual harassment in the camp with regard to all dependent variables.

Table 7. ANOVA Results from Table 4 (Victim's Responses to Harassment)

\begin{tabular}{|c|c|c|c|c|c|}
\hline Variable & Category & $M$ & $S D$ & $F$ & $p$ \\
\hline \multirow[t]{2}{*}{ Age } & $15-20$ & 2.54 & .413 & 1.280 & .260 \\
\hline & $21-24$ & 2.59 & .403 & & \\
\hline \multirow[t]{4}{*}{ Marital status } & Single & 2.52 & .354 & 1.121 & .342 \\
\hline & Married & 2.58 & .432 & & \\
\hline & Divorced & 2.43 & .459 & & \\
\hline & Widow & 2.60 & .592 & & \\
\hline \multirow[t]{5}{*}{ Education } & Illiterate & 2.52 & .396 & .976 & .422 \\
\hline & Elementary & 2.51 & .442 & & \\
\hline & Preparatory & 2.56 & .407 & & \\
\hline & Secondary & 2.66 & .393 & & \\
\hline & University degree & 2.45 & .408 & & \\
\hline \multirow{3}{*}{$\begin{array}{l}\text { Where have } \\
\text { harassed? }\end{array}$} & Streets & 2.55 & .407 & .013 & .987 \\
\hline & Shops (mini market) & 2.55 & .418 & & \\
\hline & Restrooms & 2.57 & .407 & & \\
\hline \multirow{4}{*}{$\begin{array}{l}\text { How many times have you been } \\
\text { harassed? }\end{array}$} & Once & 2.58 & .499 & .851 & .468 \\
\hline & Twice & 2.60 & .436 & & \\
\hline & Three times & 2.51 & .335 & & \\
\hline & Four times or more & 2.54 & .412 & & \\
\hline \multirow{4}{*}{$\begin{array}{l}\text { At what time of day did the } \\
\text { harassment occur? }\end{array}$} & In the morning & 2.55 & .468 & .129 & .943 \\
\hline & At noon & 2.56 & .436 & & \\
\hline & In the evening & 2.53 & .350 & & \\
\hline & At multiple times & 2.58 & .401 & & \\
\hline \multirow{4}{*}{$\begin{array}{l}\text { What form of sexual } \\
\text { harassment did you undergo? }\end{array}$} & Verbal & 2.50 & .406 & .843 & .472 \\
\hline & Symbolic & 2.55 & .484 & & \\
\hline & Behavioral & 2.62 & .418 & & \\
\hline & Social media & 2.60 & .335 & & \\
\hline
\end{tabular}

Note: $\alpha=.05$.

The results displayed in Table 7 show that there are no statistically significant differences in responding to harassment with regard to all dependent variables. 
International Journal of Child, Youth and Family Studies (2019) 10(4.1): 24-43

Table 8. ANOVA Results from Table 5 (Pervasive Harassment Incidents)

\begin{tabular}{|c|c|c|c|c|c|}
\hline Variable & Category & $M$ & $S t D$ & $F$ & $p$ \\
\hline \multirow[t]{2}{*}{ Age } & $15-20$ & 3.07 & .357 & 6.382 & .012 \\
\hline & $21-24$ & 3.13 & .272 & & \\
\hline \multirow[t]{4}{*}{ Marital status } & Single & 3.08 & .316 & .748 & .525 \\
\hline & Married & 3.11 & .351 & & \\
\hline & Divorced & 3.08 & .219 & & \\
\hline & Widow & 2.98 & .276 & & \\
\hline \multirow[t]{5}{*}{ Education } & Illiterate & 3.03 & .401 & 1.277 & .281 \\
\hline & Elementary & 3.09 & .408 & & \\
\hline & Preparatory & 3.11 & .316 & & \\
\hline & Secondary & 3.07 & .293 & & \\
\hline & University degree & 2.98 & .313 & & \\
\hline \multirow{3}{*}{$\begin{array}{l}\text { Where have } \\
\text { harassed? }\end{array}$} & Streets & 3.02 & .335 & 1.553 & .215 \\
\hline & Shops (mini market) & 3.13 & .334 & & \\
\hline & Restrooms & 3.13 & .304 & & \\
\hline \multirow{4}{*}{$\begin{array}{l}\text { How many times have you been } \\
\text { harassed? }\end{array}$} & Once & 3.22 & .284 & 2.465 & .064 \\
\hline & Twice & 3.15 & .295 & & \\
\hline & Three times & 3.06 & .272 & & \\
\hline & Four times or more & 3.05 & .379 & & \\
\hline \multirow{4}{*}{$\begin{array}{l}\text { At what time of day did the } \\
\text { harassment occur? }\end{array}$} & In the morning & 3.15 & .356 & 2.190 & .091 \\
\hline & At noon & 2.99 & .367 & & \\
\hline & In the evening & 3.16 & .269 & & \\
\hline & At multiple times & 3.11 & .306 & & \\
\hline \multirow{4}{*}{$\begin{array}{l}\text { What form of sexual } \\
\text { harassment did you undergo? }\end{array}$} & Verbal & 3.07 & .372 & .627 & .598 \\
\hline & Symbolic & 3.10 & .295 & & \\
\hline & Behavioral & 3.08 & .265 & & \\
\hline & Social media & 3.13 & .340 & & \\
\hline
\end{tabular}

Note: $\alpha=.05$.

Finally, the results provided in Table 8 show that there are no statistically significant differences in the harassment incidents that are seen as pervasive in the camp with regard to all dependent variables, except for ages 21 to 24 . We suggest that the 3 negative results indicate that sexual harassment in the camp is pervasive and occurs in all of its probable forms, in addition to the fact that the camp environment could be described as tolerant of sexual harassment. These negative results indicate that sexual harassment strongly impacts the lives of females in the camp.

\section{Discussion}

This study aimed at documenting the self-reported sexual harassment of Syrian female refugees in the Za'atari refugee camp in Jordan. To achieve this goal, a purposive sample of 187 Syrian female refugees was selected. As expected, the results showed that the participants felt that the environment of the camp played an important role in motivating males to harass females, owing to the weakness of controlling processes and the lack of sanctions upon deviant behaviors. In the 
view of participants, the official authorities had relinquished their responsibility to create a safe environment in the camp; at the same time, families had relinquished their role in socialization. Participants felt males did not respect the regulations of the camp, or its moral and social norms, and thus felt free to follow their destructive impulses without fear of sanctions or punishment.

Additionally, our results revealed that participants responded to sexual harassment by keeping silent for fear of making their situation worse by provoking conflict within their families. They reported informing close friends about the harassment, but not their families or the camp authorities. From a gender perspective, females in Syrian culture are expected to uphold the honor of the family by behaving morally and responsibly: their behaviors are seen as affecting not just them as individuals, but their families as well, so that the reputation of the individual is a reflection of the reputation of family and vice versa. Because of the strong extended social bonds and family solidarity and cohesion in Syrian society, and Arab society in general, the reputation of the individual is considered a reflection of the reputation of the family, and vice versa. For this reason, victims often fear to share incidents of sexual harassment with family members.

Furthermore, our findings show that females were subjected to numerous forms of sexual harassment, including hearing sexual jokes and sexual expressions, and being subjected to suggestive looks, sexual letters, and unwanted touching. This is consistent with the absence already noted of regulations, control, and socialization. The frequency and intensity of sexual harassment indicated a deepening problem in the camp, and an increasingly challenging social environment for the women who had to endure it.

Syrian women refugees in the camp live in difficult circumstances indeed. They are unable to meet their own basic needs or to escape from their disastrous reality. Rates of school drop-out and unemployment are high among them. A lack of available psychological support and guidance makes matters worse (Al-Hurriat, 2017). This desperate situation engenders psychological disorders that manifest as fear, worry, depression, and social isolation: some refugees reported fearing to be alone in their tents and having nightmares after learning of the attempted rape of Fatin by maintenance workers ("Shocking stories", 2013).

Many female refugees have had to agree to otherwise unwanted marriages in return for safety from violence and sexual harassment (Abu-Tarboush, 2014). The practice of exploiting women in sex trading under the name of early marriage is carried out by organized criminal elements (Abu-Tarboush, 2014). Many such marriages have resulted in the wives being either abandoned or obliged by their husbands to practise prostitution (Al-Ghazali, 2018).

The lack of food, drink, heating facilities, and electricity have combined with unemployment to encourage opportunists to supply these necessities illegally. The sex trade has spread in the camp, and hundreds of Syrian women have been sold through prostitution or by compulsory marriage (Migdadi, 2017). 
Most females reported that they were reluctant to report sexual harassment for fear of being stigmatized. Many women stated that married women who report harassment to their husbands may have to put up with their husbands restricting their freedom and monitoring their movements in order to protect them. Some participants were afraid to visit the bathrooms alone at night lest they be sexually harassed. Some families reported that they had even jury-rigged their own bathrooms, a practice that could lead to health problems in the tents.

Furthermore, researchers noted that Syrian women also face obstacles to getting services in the camp. For example, women who care for children, patients, or injured family members find it difficult to get the necessary services to properly help them. We believe that, taken together, our results indicate that the Zata'ari camp environment is not secure and safe for females and that authorities of the camp should therefore devise a serious action plan to remedy this by increasing the number of community policemen and police stations in the camp, and by establishing couselling units, rehabilitation centers for both males and females, and hot lines to the community police department. Furthermore, practitioners in the camp should recognize and act on the need to establish committees representing women in the camp to lead in organizing against the GBV they face. It is hoped that such committees would both help reduce sexual harassment and premature marriage, and increase awareness of the challenges that women and girls face in the refugee camps.

Further research on sexual harassment of Syrian female refugees should be conducted in more diverse environments including both in other refugee camps and outside the camps. In his theory of deviant behavior, Talcott Parsons draws attension to the fact that deviant behavior is a consequence of non-conformity, which means that social norms are not clear and not integrated into daily life. There is an important range of problems concerning the difficulty of conformity with a normative pattern that focuses on the nature of the pattern itself. For Parsons (1964), this concerns the question of how far the expectations of conformity are or are not specific and detailed. As he suggests, by increasing anxiety, the impact of the confusion or absence of expectations would lead to the escalation of the motivations for the deviant behavior (pp. 267-270). From this perspective, future research should be focused on males who commited sexual harassment against females to arrive at causal explanations for such an act.

From Parson's (1964) perspective, four social mechanisms are needed in order to eliminate sexual harassment: (1) an obvious social order including strict, specified, and detailed social norms; (2) socialization: internalization of the social order by individuals; (3) social control: individuals should conform to the social order and its regulations; and (4) respect for the discipline that may be imposed on individual actors should be maintained by ensuring that appropriate sanctions and punishments are applied.

Furthermore, an attempt should be made to conduct studies on the concequences of sexual harassment on the female victims. We observed in the field that girls who have been sexually harassed were afraid, hesitantt, not self confident, worried, and frustrated. 
International Journal of Child, Youth and Family Studies (2019) 10(4.1): 24-43

\section{References}

Abu Tarboush, R. (2014). The social and psychological effects of the Syrian crisis on Syrian refugee children in Jordan (Unpublished master's thesis). University of Jordan, Amman, Jordan.

Al-Ghazali, N. (2018). Displaced people in Syria and Syrian refugees in Lebanon, Jordan, Turkey, Iraq, Egypt. Damascus Center for Theoretical Studies and Civil Rights.

Al-Hourani, M. (2016). The emergent roles of Syrian women refugees in Jordan: Rethinking theory and its frontiers. Journal of Social Sciences, Kuwait, 44(2), 146-176.

Al-Jundi, A. (2016). Syrian women victims of prostitution and forced marriage networks. Journal of Juhayna, 85. Retrieved from http://jouhina.com/magazine/archive_article.php?id=3675

Al-Khateeb. J. (2013, December 20). Syrian refugees: Between sex trade and rape and harassment. Al-Bawabh News. Retrieved from http://www.albawabhnews.com/277662

Al-Shreefeen, A., \& Al-Rifa'I, A. (2016). Psychological security in light of gender and marital status: A comparative study between a sample of Jordanians and another sample of Syrian refugees. Proceedings of The Second International Conference for Refugees in the Middle East: "Human Security: International Community Obligations and Hosting Communities' Role” (pp. 191-213).

Amnesty International: Syrian refugees in Zaatari camp live in fear of sexual violence. (2013, October 31). Al-Quds Al-Arabia Press. Retrieved from https://www.amnesty.org/ar/latest/campaigns/2013/09/early-marriage-and-harassment-ofsyrian-refugee-women-and-girls-in-jordan

Asaf, Y. (2017). Syrian women and the refugee crisis: Surviving the conflict, building peace, and taking new gender roles. Social Sciences, 6(3), 110-138. doi:10.3390/socsci6030110

Department of Statistics. (2015). Jordan Statistical Yearbook [No. 66]. Amman, Jordan: Author.

Essaid, A., Usta, J., Shukri, S., El Gharaibeh, Y., Abu Taleb, H., Awwad, N., .. \& \& Clark, C. J. (2015). Gender based violence against women and girls displaced by the Syrian conflict in south Lebanon and north Jordan: Scope of violence and health correlates. Madrid, Spain: Alianza por la Solidaridad. Retrieved from https://www.alianzaporlasolidaridad.org/wpcontent/uploads/GBV-Against-Women-and-Girl-Syrian-Refugees-in-Lebanon-and-JordanFINAL.pdf

Haddadin, S. (2014, April 30). The study reveals violations against Syrian refugees. Al-Rai Newspaper of Jordan. 
International Journal of Child, Youth and Family Studies (2019) 10(4.1): 24-43

Hattar-Pollara, M. (2019). Barriers to education of Syrian refugee girls in Jordan: Gender-based threats and challenges. Journal of Nursing Scholarship, 51(3), 241-251.

doi:10.1111/jnu. 12480

Inter-Agency Working Group on Reproductive Health in Crisis. (n. d.). Minimum Initial Service Package. Retrieved from http://iawg.net/areas-of-focus/misp/

Krause, S., Williams, H., Onyango, M. A., Sami, S., Doedens, W., Giga, N., ... Tomczyk, B. (2015). Reproductive health services for Syrian refugees in Zaatri Camp and Irbid City, Hashemite Kingdom of Jordan: An evaluation of the minimum initial services package. Conflict and Health, 9(Suppl. 1), S4. doi:10.1186/1752-1505-9-S1-S4

Mas'ood, G. (2017) Syrian women refugees: All women of the world are experiencing the same dilemma - Harassment, rape, marriage of minors, and maintenance of families. Wlahawogohokhra. Retrieved from https://wlahawogohokhra.com/4427/

Migdadi, Y. (2017, April). Post-traumatic stress disorder among Syrian refugee children in Zaatari Camp. Paper submitted to the conference of Education:Its challenges and prospects, Irbid, Jordan.

Parsons, T. (1964). The social system (2nd ed.). New York, NY: Free Press.

Samari, G. (2017). Syrian refugee women's health in Lebanon, Turkey, and Jordan and recommendations for improved practice. World Medical \& Health Policy, 9(2), 255-274. doi:10.1002/wmh3.231

Sami, S., Williams, H. A., Krause, S., Onyango, M. A., Burton, A., \& Tomczyk, B. (2014). Responding to the Syrian crisis: The needs of women and girls. The Lancet, 383(9923), 1179-1181. doi:10.1016/S0140-6736(13)62034-6

Sherlock, R., \& Malouf, C. (2013, January 23). Syrian girls 'sold' into forced marriages. The Telegraph. Retrieved from https://www.telegraph.co.uk

Syrian women describe the suffering of sexual harassment in Za'atari Camp. (2012, December 12). Jafra News. Retrieved from https://www.jfranews.com.jo/post.php?id=49200

UN Women. (2013). Gender-Based violence and child protection among Syrian refugees in Jordan, with a focus on early marriage [Inter-agency assessment]. Amman, Jordan: Communications and Advocacy Section of UN Women. Retrieved from https://data2.unhcr.org/en/documents/download/39522

United Nations High Commissioner for Refugees. (2008). UNHCR handbook for the protection of women and girls. Geneva, Switzerland: Author. Retrieved from https://www.unhcr.org/protection/women/47cfa9fe2/unhcr-handbook-protection-womengirls-first-edition-complete-publication.html. 
International Journal of Child, Youth and Family Studies (2019) 10(4.1): 24-43

Za'atari Camp: A theater of sexual abuse and extortion to obtain sex in the marriage. (2013, July 25). Al-Mada.org. Retrieved from https://www.almada.org/ 
International Journal of Child, Youth and Family Studies (2019) 10(4.1): 24-43

\section{Appendix A}

\section{Questionnaire}

1. Age

2. Marital status

3. Educational attainment

4. Have you ever been sexually harassed in the camp?

If you answered yes to question 4, please also answer the following questions.

5. Where you have been sexually harassed?

6. How many times have you been harassed?

7. At what time of day did the harassment occur?

8. What form of sexual harassment did you undergo?

9. Do you believe that sexual harassment is pervasive in the camp?

\section{Motivational environment of sexual harassment in the camp}

Males feel empowered to sexually harass females because:

1. There are no sanctions against harassment in the camp

2. There are no controlling procedures in the camp

3. Males recognize that there is an absence of surveillance

4. Males recognize that they are able to violate rules without being punished

5. The camp environment doesn't provide the minimum level of deterrence

6. There is an absence of official authorities to prevent harassment

7. There are no clear procedures for punishing harassment

8. Males are not regulated by moral guidance from their families

9. Males are able to do what they want in the camp

\section{Victim's response to harassment}

1. Keeping silent to avoid worsening the problem

2. Resisting the man strongly and loudly

3. Telling family members immediately after the incident

4. Being too scared to do anything

5. Telling official authorities in the camp

6. Expressing satisfaction at successfully avoiding further incidents

7. Telling close friends only

3. Which of the following harassment types do you see as pervasive in the camp?

1. Females being exposed to sexual expressions that violate modesty

2. Males making sexual jokes within the hearing of females

3. Females hearing expressions that make them uncomfortable

4. Females receiving sexually suggestive and aggressive looks

5. Males chasing females in the camp

6. Uninvited pressure for sexual favors

7. Males luring females to obtain sexual favors 
International Journal of Child, Youth and Family Studies (2019) 10(4.1): 24-43

8. Males making sexual remarks to females

9. Males touching females or leaning over them

10. Females receiving threats to keep silent after being harassed

11. Females receiving letters, telephone calls, or materials of a sexual nature 